\title{
THE SEARCH FOR A VECTOR OF STRAWBERRY LETHAL YELLOWS (SLY) IN NEW ZEALAND
}

\author{
J.G. CHARLES ${ }^{1}$, D.J. ALLAN ${ }^{1}$, M.T. ANDERSEN ${ }^{1}$, G. LANGFORD ${ }^{2}$ \\ and D. MOSSOP ${ }^{3}$
}

\author{
${ }^{1}$ HortResearch, Private Bag 92 169, Auckland, New Zealand \\ ${ }^{2}$ HortResearch, P.O.Box 51, Lincoln, New Zealand \\ ${ }^{3}$ P.O. Box 33, Waihi Beach, New Zealand
}

\begin{abstract}
Strawberry lethal yellows (SLY) is a phytoplasma disease that affects strawberry plants in New Zealand and Australia. Although it has been established that this phytoplasma ("Candidatus Phytoplasma australiense") is responsible for causing diseases in a number of other plant hosts, an insect responsible for its spread still remains to be determined. To identify potential insect vectors, yellow sticky traps were established at two properties in the Bay of Plenty from planting (early October 2001) until harvest (May 2002). Leafhoppers caught in the traps until March 2002 and by sweep-netting the surrounding habitats in February were identified and tested for the presence of phytoplasma using Polymerase Chain Reaction (PCR). Arawa variegata and Recilia hospes (both Cicadellidae) were the commonest leafhoppers trapped. Phytoplasma was detected in first and second generation A. variegata in October and February respectively, and in second generation $R$. hospes in February. The implications of this work for future SLY studies is discussed.

Keywords: Phytoplasmas, leafhoppers, strawberries, New Zealand.
\end{abstract}

\section{INTRODUCTION}

Symptoms of SLY were first reported in New Zealand more than 20 years ago. The causal agent of the disease was initially considered to be a virus, but has recently been confirmed as a phytoplasma (Andersen et al. 1998), a type of bacterium that has yet to be cultured in vitro. Molecular biology has added significantly to our knowledge of the phylogeny of phytoplasmas. These details have helped to formulate possible classifications of phytoplasmas, such that the organism associated with SLY, Phormium yellow leaf (PYL), Australian grapevine yellows (AGY), papaya dieback (PDB) and Cordyline sudden decline (CSD) all belong to "Candidatus Phytoplasma australiense" (Andersen et al. 1998, 2001). Universal primers and techniques have been developed that allow the detection of the phytoplasmas in both plants and insects.

In the past few years SLY has been a persistent problem for the growers that produce runner plants for the commercial strawberry industry in New Zealand. The symptoms of SLY in runner beds are usually first seen on the mother plants in early-mid November, and then continuously until harvest in May. Because it is not known how long it takes for symptoms to appear after inoculation, it is not known whether there are multiple infection events from November until May, or a discrete infection period leading to progressive appearance of symptoms. It is also possible that SLY may originate in elite beds and remain symptomless until the following season in the runner beds. SLY is also present in production crops, but may be mistaken for symptoms of Phytophthora root rot fungi.

Phytoplasma diseases are managed by use of resistant plant varieties, if available; by eliminating alternative plants that may harbour the micro-organism; or by controlling the insect vectors that spread them. This last strategy may entail spraying to eliminate or 
reduce vector numbers at key times in the growing season. Insect vectors for phytoplasmas are phloem feeders, usually leafhoppers or planthoppers, and occasionally psyllids. The only known vector for " $\mathrm{Ca}$ P. australiense" is Oliarus atkinsoni (Cixiidae), which is associated with the spread of PYL. This indigenous planthopper feeds only on Phormium spp. and is therefore not believed to be the vector responsible for spreading SLY. The vectors of the other diseases associated with " $\mathrm{Ca}$ P. australiense" are unknown. There are no known leafhopper or planthopper pests of strawberries in New Zealand. Two species of Typhlocybinae (Ribautiana tenerrima and Zygina dumbletoni) have occasionally been collected from strawberries (Andersen et al. 1998), but the frequency with which they are found does not appear to relate to the frequency of SLY, so there are no obvious vectors of the disease.

The objective of the current study was to collect possible candidates from areas of high infection and test them for the presence of phytoplasma using Polymerase Chain Reaction (PCR). Although the presence of a phytoplasma in an insect does not indicate that the insect is necessarily a vector since an insect can acquire phytoplasmas through feeding but lack the ability to transmit them to other plants, it would provide significant information for future experiments.

\section{METHODS}

Leafhoppers were collected from two commercial runner producing properties in Katikati (Bay of Plenty), both of which had histories of SLY infestations. Four or six leafhopper traps were placed within each property from early October 2001 (immediately after planting) until harvest in May 2002. The traps were $10 \mathrm{~cm}$ x $20 \mathrm{~cm}$ double-sided yellow sticky traps hung from posts at about $1 \mathrm{~m}$ above the strawberry beds. The traps were replaced fortnightly. High winds in late November and December tore some traps from their supports and resulted in reduced catches. All insects caught until the end of March 2002 were examined under a binocular microscope, and leafhoppers (Hemiptera: Cicadellidae) and Psyllidae were removed to $70 \%$ alcohol. Searches were also made by sweep-netting various potential leafhopper habitats around the strawberry properties in February, following trap catches that corresponded to the expected start of the summer generation of adult leafhoppers (Prestidge 1989). Species of Cicadellidae can usually only reliably be identified by the male genitalia, so intact males from the trap catches and subsamples of males from the sweepnet catches were dissected for identification. Most of the remaining leafhoppers, both male and female, were examined for the presence of phytoplasmas.

DNA was extracted from 1-5 insects per sample using a standard SDS-Proteinase K method (Newcomb \& Gleeson 1998). Thirty-six samples were tested for SLY using nested-PCR with phytoplasma-specific primers to either the 16S rRNA or tuf genes. Nested-PCR involves two separate amplifications (per gene) with two sets of primers the second of which lies within the DNA fragment amplified by the first. Primers used in nested-PCR were R16F2 and R16R2 ( $1^{\text {st }}$ stage $)$ and NGF and NGR $\left(2^{\text {nd }}\right.$ stage $)$ for the 16S rRNA gene (Andersen et al. 1998); fTufAY and rTufAY ( $\left(1^{\text {st }}\right.$ stage) (Schneider et al. 1997) and Tuf1FA (5'-GATAGTGTAATGCCTCA-3') and Tuf4R (5'CCTGCTTGAGCAAAATCTA-3') (2 $2^{\text {nd }}$ stage) for the tuf gene. Conditions for PCR were as described in Andersen et al. 2001.

\section{Seasonal trapping}

\section{RESULTS}

Adult Cicadellidae were found in the sticky traps periodically throughout the season, but there was one large peak of activity during late October (Table 1) corresponding to first generations of Arawa variegata (12) and Recilia hospes (20). Second generation A. variegata (4) and $R$. hospes (1) were trapped during January, which triggered a search of various habitats adjacent to the strawberry fields in February. Adults and a few nymphs of both species were collected by sweepnet from ryegrass pasture and weeds. 
TABLE 1: Numbers of insects caught from combined sticky trap catches at two strawberry properties at Katikati.

\begin{tabular}{|c|c|c|c|c|}
\hline Date & A. variegata & R. hospes & Typhlocybinae & Psyllidae \\
\hline $10 \mathrm{Sep}-21 \mathrm{Sep}$ & & & & 3 \\
\hline $21 \mathrm{Sep}-3 \mathrm{Oct}$ & 1 & & 2 & 1 \\
\hline $3 \mathrm{Oct}-16 \mathrm{Oct}$ & & & 1 & 2 \\
\hline 17 Oct -30 Oct & 12 & 20 & 1 & 25 \\
\hline 30 Oct -14 Nov & & & 1 & 1 \\
\hline 14 Nov - 29 Nov & & & & 6 \\
\hline \multicolumn{5}{|l|}{29 Nov - 13 Dec } \\
\hline \multicolumn{5}{|l|}{$13 \mathrm{Dec}-30 \mathrm{Dec}$} \\
\hline 30 Dec -13 Jan & 3 & & & 2 \\
\hline 13 Jan - 27 Jan & 1 & 1 & 1 & \\
\hline 27 Jan - 10 Feb & & & & \\
\hline $10 \mathrm{Feb}-24 \mathrm{Feb}$ & & & & 21 \\
\hline 24 Feb - 10 Mar & & & & \\
\hline $10 \mathrm{Mar}$ - $24 \mathrm{Mar}$ & & & & 1 \\
\hline
\end{tabular}

Little is known of the biology of these rather similar looking species, other than they are bivoltine and overwinter in the egg stage (Prestidge 1989). Arawa variegata is an endemic species, found only in New Zealand but throughout the North and South Islands. It has been recorded from pasture, lucerne (Medicago sativa) and tussock (Chionochloa australis). Recilia hospes was first recorded from Hawaii and has since been found in Guam, Fiji and Australia. In New Zealand it is widely distributed through the North and South Islands and has been collected from grass, sedges, low plants and shrubs (Knight 1975). Neither species has been collected from strawberries.

A few $(<10)$ leafhoppers were caught on the sticky traps in November. These were sufficiently damaged that their identity could not be confirmed, but they were similar in overall appearance to A. variegata or $R$. hospes. The only other leafhoppers caught on the sticky traps were seven unidentified Typhlocybinae. At least seven species of Psyllidae were also recovered in low numbers through the season.

\section{Detection of phytoplasmas}

Four samples gave positive bands of the expected size with $16 \mathrm{~S}$ primers. They were A. variegata collected in October and February from a sticky trap and sweepnet respectively, and $R$. hospes collected in November and February also from a sticky trap and sweepnet respectively (Fig. 1). One of these, A. variegata collected in October, gave a positive band for both sets of primers. Samples of Typhlocybinae and Psyllidae did not produce any positive phytoplasma bands on PCR amplification.

\section{DISCUSSION}

This work has shown that adults of two common native leafhopper species, present in pasture surrounding strawberry runner beds, frequently flew over the strawberry plants. It is not known how long individuals spent there, or whether they fed on the strawberries, but it seems probable that they at least probed the plants to test for palatability. The work also showed that at least some of the leafhoppers had acquired phytoplasmas from as yet unknown host plants. The 16S rRNA and tuf primers are universal for all phytoplasmas, so it is not yet known if those in the leafhoppers were the same as those associated with SLY. Nevertheless, the fact that phytoplasma-infected leafhoppers visited strawberry plants which subsequently developed SLY symptoms encourages us to pursue this line of investigation. There remain many uncertainties, not least of which is that the presence of a phytoplasma in a leafhopper does not mean it is a vector. However, we can at least now erect and test hypotheses using known species of leafhoppers. Further 
a

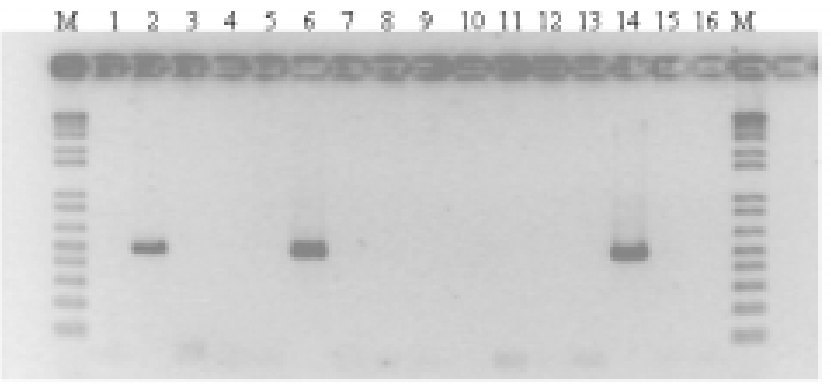

b

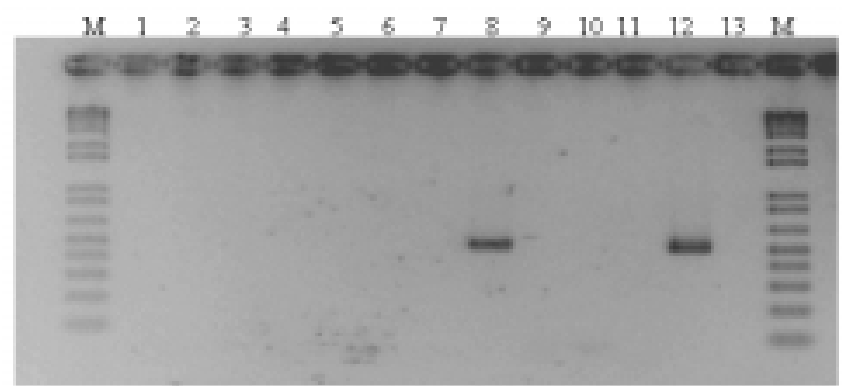

FIGURE 1: Agarose gel showing positive results of nested-PCR of DNA from leafhopper samples. (a) Lanes 1-8 are from 16Sr RNA gene primers (2nd stage) and Lanes 9-16 are from Tuf primers (2nd stage); Lanes 6 and 14 are positive controls; Lane 2 is a $R$. hospes sample taken in February. (b) Lanes 1-13 are 16Sr RNA gene primers (2nd stage); Lane 12 is a positive control; Lane 8 was from a leafhopper (? $R$. hospes) caught in a trap in November.

trapping will improve our knowledge of the seasonal phenology of leafhoppers that visit strawberries and allow possible targeted control measures to be investigated, even without full knowledge of the transmission ecology. Simultaneous study of the occurrence of the SLY phytoplasma in other hosts of these leafhoppers will continue to add to our knowledge of the probably complex set of multi-trophic interactions among these organisms.

\section{ACKNOWLEDGEMENTS}

We thank Marie-Claude Larivière and Pam Dale respectively for identifying the leafhoppers and psyllids. This work was partly funded by NZ Berryfruit Propagators Ltd.

\section{REFERENCES}

Andersen, M.T.; Longmore, J.; Liefting, L.W.; Wood, G.A.; Sutherland, P.W.; Beck, D.L.; Forster, R.L.S. 1998: Phormium yellow leaf phytoplasma is associated with strawberry lethal yellows disease in New Zealand. Plant Disease 82: 606-609. 
Andersen, M.T.; Beever, R.E.; Sutherland, P.W.; Forster, R.L.S. 2001: Association of "Candidatus Phytoplasma australiense" with Sudden Decline of Cabbage Tree in New Zealand. Plant Disease 85: 462-469.

Knight, W.J. 1975: Deltocephalinae of New Zealand (Homoptera: Cicadellidae). N. Z. J. Zool. 2:169-208.

Newcomb, R.D.; Gleeson, D.M. 1998: Pheromone evolution within the genera Ctenopseustis and Planotortrix (Lepidoptera: Tortricidae) inferred from a phylogeny based on cytochrome oxidase I gene variation. Biochem. Syst. Ecol. 26: 473-484.

Prestidge, R.A. 1989: Preliminary observations on the grassland leafhopper fauna of the central North Island Volcanic Plateau. N.Z.Entomol. 12: 54-57.

Schneider, B.; Gibb, K.S.; Seemuler, E. 1997: Sequence and RFLP analysis of the elongation factor Tu gene used in differentiation and classification of phytoplasmas. Microbiol. 143: 3381-3389. 